\title{
Genres of Participation in Social Networking Systems: A Study of the 2009 Norwegian Parliamentary Election
}

\author{
Marius Johannessen \\ University of Agder, Department of Information Systems \\ Service box 422, NO-4604 Kristiansand, Norway
}

\begin{abstract}
In the Norwegian context, eParticipation in the form of online campaigning has been on the agenda since 2001. After Obama's successful presidential campaign in 2008, expectations about the use of SNS in the Norwegian parliamentary election were high.

This study explores genres of participation in the early stages of the 2009 Norwegian parliamentary election campaign. The main finding is that the political parties have seen the need for a presence in SNS', and that a genre repertoire for political communication through SNS is beginning to evolve. However, there is little agreement between citizens and politicians about how the different genres should be enacted. Further work with genres is presented as a possible solution to lessening this communication gap.
\end{abstract}

Keywords: eParticipation, Social Networking Systems, Genre theory, Genre Repertoire, election campaign.

\section{Introduction}

Online campaigning has been on the agenda in Norway since the parliamentary election in 2001. Back then the Internet played a marginal role, but it was expected that this would change in coming election campaigns [1]. Barack Obama's successful online campaign in 2008 created expectations that the political parties in Norway would use social networking systems (SNS) with a similar degree of success [2].

The Norwegian research project power and democracy ${ }^{1}$ conducted a study of the state of democracy in Norway between 1998 and 2003. One of the main conclusions of the study was that representative democracy is in decline. The loyalty to political parties and the broad social movements that characterized the period following World War II is replaced by an electorate that moves from one party to the next, more or less guided by the current headlines in the media. Single issues have become more important than party politics. This means that power is slowly moving from the parliament towards lobbying and non-governmental organizations (NGO's) [3].

As a research field, eParticipation examines how to include citizens in the public discourse. Online campaigning and participation in the decision-making process are typical eParticipation activities [4]. There is an increasing belief in several countries

\footnotetext{
${ }^{1}$ For information in English, see

http://www.sv.uio.no/mutr/english/index.html 
that eParticipation can be an important factor for strengthening democracy $[4,5]$, and in Norway, politicians are signaling that they want more citizen dialogue and userinvolvement in the political process [6].

Many eParticipation projects fail to get a "representative sample of the population" to participate [7]. In contrast, SNS' have a large user base as well as functionality that could help foster participation. The massive interest for SNS use in the Norwegian election, and Obama's success with SNS, makes this an interesting area for eParticipation research. The purpose of this paper is to examine the SNS communicative strategies of Norwegian political parties in the 2009 parliamentary election, and to examine whether there is evidence of an emerging genre repertoire of political communication in SNS. Genre theory is used as theoretical lens for the study.

The rest of the paper is structured as follows: Chapter two provides a brief literature review of social networks in eParticipation and election campaigns as a form of eParticipation. Chapters three and four present the research method and findings of the study, and Chapter five provides a summary of the paper with some possible directions for future research.

\section{Background and Prior Research}

A functioning democracy requires good communication between citizens and their elected representatives [8]. Communication is hindered by the fact that traditional political engagement through parties is in decline, being replaced by engagement in single issues and various interest groups [3]. To improve communication, political parties have begun experimenting with information and communication technologies (ICTs), as this has proven effective in the delivery of online services [9]. There is as yet little evidence of success in eParticipation projects. Several case studies point out potential benefits [10], but there are some challenges involved. Many politicians are reluctant, because they feel that eParticipation goes against the values of representative democracy, or because they are uncertain about technology use [11]. There is also disagreement about the outcome of dialogue in eParticipation projects. Politicians mainly want to inform, while citizens want to influence the decision-making process [12]. To shorten the gap between citizen and politician, Päivärinta \& Sæbø [13] have developed four different models of democracy, ranging from partisan and liberal democracy (where politicians set the agenda) to deliberative and direct democracy (where citizens set the agenda). Democracy models could be used to create an explicit agreement on the outcome of eParticipation projects.

Another challenge to eParticipation is that many projects have few users and fail to get a "representative sample of the population" to participate [7]. Despite this, citizens are active users of the Internet in other areas. We share information and content, participate in online networks and even exchange political ideas in various SNSs [6]. An increasing number of private companies are using SNSs to communicate with clients and customers[14], and customers are beginning to expect this type of dialogue [15]. Media use is becoming ever more fragmented. In the past you would reach everyone through TV or printed newspapers. Today people access news in a number of different sources, making it difficult to reach out to everyone. By using SNS, it becomes easier to utilize the "long tail", the many small internet-based services where different groups of people go for information [16-18]. 


\subsection{Social Networking Services}

Web 2.0, social networks, social media and new media. There are many labels attached to the new phenomena we observe in digital media today. The concept of web 2.0 first emerged in 2005, when O'Reilly Publishing examined the companies that survived the burst of the "dot com bubble". These companies had something in common; Their services got more useful as the user base grew, utilized "collective intelligence" through tags and recommendations, and relied heavily on user-generated content [16]. User-generated content and user-involvement have been put forth as the most important elements of web $2.0[17,19]$. Because of the study's focus on online campaigning, this paper will use the concept of social networks/social networking services (SNS), and examine how these were used by political parties to communicate with citizens. SNSs are web-based services where users can 1) create and maintain a public or private profile. 2) create a list of other users they are connected to, and 3) see their own and others' contact lists [20]. The most popular SNSs are those that focus on user-generated content, participation, openness and network effects [21].

Social networking is not mainly about technology, but about covering people's needs for access to and sharing of information, collaboration and the creation of identity and self. As such, SNS should be treated more as a cultural than technological phenomenon [22]. To reap the benefits of SNS, owners of information needs to open their data, think in terms of collaborative production of ideas and content, and to share ideas with others in order to create better information[15].

\subsection{Election Campaigns and Social Networks}

Campaigning is all about getting the message out to the public, and convincing the public that your party has the best policy. The election campaign has a very big influence on the outcome of the parliamentary election. More than $40 \%$ of Norwegian voters wait until the final weeks of the campaign before deciding who gets their vote, and many change their mind several times during the campaign [23]. Younger voters are more likely to cast their vote differently from one election to the next [24]. When the Norwegian newspapers became politically independent, political parties lost the power to decide what should be on the public agenda [3]. The media has taken over this role, and are trying to write about the things they believe voters are concerned about $[3,24]$. Web statistics site alexa.com shows that younger age groups are still a majority in social networking sites such as Twitter and Facebook, and SNSs are among the most visited web sites in the world. Politicians wishing to influence the public should therefore have a presence in SNS, a presence that could help in taking back some of the agenda-setting power that the media currently possess.

Norwegian political parties have used the Internet in election campaigns for years, but SNS was first introduced in 2007. Inspired by Barack Obama, the 2009 election was the first time Norwegian parties were expected to really go in for SNS as a campaign tool [25]. Norwegian parties started using the Internet during the election campaign in 2001. This first attempt mainly produced digital copies of party documents and brochures, but even so the number of visitors to these sites increased a lot during the campaign [1]. At the 2005 parliamentary election, all the major parties had good web sites, and the Internet was seen as a natural part of the campaign. 
However, users still preferred other media, with only $13 \%$ of voters accessing the web sites of political parties [26]. In the 2007 local and regional elections parties had begun experimenting with SNS, publishing videos to Youtube, creating profiles on Facebook and writing blogs [27]. Facebook provided an outlet for the party grassroots and sympathizers to some extent [27], but there was little evidence of a real dialogue between politicians and citizens [28].

\section{Method}

The study was conducted using a qualitative, interpretive approach. Data was collected through semi-structured interviews with representatives from the seven political parties that were represented in the parliament before the election (Socialist Left, Labor, Center Party, Liberals, Christian people's party, Conservatives and the Progress Party). Five interviews were made face to face, while two of the parties only had time for e-mail interviews. All of the interview subjects were hired by their respective parties to work with social networking strategies. The Interviews lasted between 40 and 77 minutes, and were taped and transcribed. To create a more complete account of the parties' election campaigns, observation and analysis of content and interaction in the SNSs used by the parties were applied. This made it possible to compare what the information workers said with what their employers, the politicians, were actually doing, and to create an overview of the genre repertoire in SNS political communication. Data was collected between March and May in 2009.

Interview questions and content analysis were guided by genre theory. Genre theory can be applied to study the role of communication in social processes. Genres evolve over time, in the interplay between institutional practice and the people communicating [29]. Genre theory provides us with a lens for detailed understanding of political communication, beyond the scope of democracy models [8] and the observation of technological functionality [30]. Originally, genres were recognized by having similar form and content, where form refers to physical and linguistic features, and content to themes and topics of the genre [29]. Later, when the Internet became more popular, functionality offered by the medium delivering the genre was added as a third construct [31]. A set of genres used by a given community can be seen as a genre repertoire[30]. The genre repertoire of a community can reveal a "rich and varied array of communicative practices" shaped by community members in response to norms, events, time pressure and media capabilities [30]. The genres reported in table 1 are based on the interviews, and the genres in table 2 are discovered by following the framework of Päivärinta et al [32].

\section{Findings}

The interview guide and guidelines for content analysis were created using the $5 \mathrm{~W} 1 \mathrm{H}$ method for genre analysis [8,33]. 5W1H consists of the questions "where, why, when, who, what" and "how". The purpose is to uncover how the genre is enacted, in what situations it is used, who the participants are and why the genre is used. By asking the same questions in interviews and content analysis, the difference between 
the parties becomes a lot clearer than from interviews only. In addition to $5 \mathrm{~W} 1 \mathrm{H}$, interview subjects were asked about their experience of the 2007 election, and what they would do differently this time.

Where - Interview subjects were asked about their party's presence in SNS and the Internet, and why they had chosen these services and not others. All of the parties have their own web site; everyone provides video and photo sharing, have a presence on Facebook and blogs. And with the exception of the Progress Party, everyone used Twitter. In addition, Labor and the Center Party also had a presence in the Norwegian SNS Origo. They all had the same explanation for why they had chosen these outlets, that they wanted a presence a) where people already are, and b) in the most relevant services for political participation.

Why - Parties agreed on why they where present in SNS, using words such as engaging citizens, dialogue and communication:

"We want to meet people where they are, be it in the store, at stands or online. That is why it is so important to us to have a presence in social media. Dialogue is the key to good solutions, and social media are a great place for dialogue" (Center Party).

Despite two-way communication being the objective, the parties are aware that this is not an easy task, and that earlier attempts have become one-way information channels: "Social media needs to be used correctly. Not just as a microphone for press releases, as we and other parties have a tendency of doing, because of a lack of time for dialogue" (Liberals)

What - Answers were a bit more varied on the question of what types of content the parties wanted to present. The party's policy was most important, and again it was pointed out that SNS could help disseminate this to groups that are difficult to reach through other channels. Labor and the Socialist Left are most explicit about spreading content that can help engage citizens in dialogue, and get party sympathizers to volunteer for "real world" activities: "To us, the most important thing is that citizens can become active participants in the offline world. We don't want people to just sit in front of their screens, watching videos. We want to inspire, to get people to talk to others, to recruit people, go knocking on doors, get people out of the chair and into the voting booths" (Labor)"

Who - There is some variation in who from the party that participates in communication through SNS. The common reply to this question was "as many as possible of those politicians who are interested", and the goal was to make party leaders and candidates for parliament to participate. Age was put forth as a barrier to participation, as older candidates were not used to communicating online, and had no wish to learn: "Some of our older candidates find the whole thing a bit scary and difficult. That is a challenge to us, to teach them that it is actually really simple once you get started." (Christian People's Party)

Others were less concerned about age, because they experienced that more and more middle-aged people are joining social networks, partially as a consequence of political presence: "We see statistics that older people are joining as well. Jens' [the prime minister] Facebook profile led to a lot of 40 to 50 year olds joining, because when the prime minister was there, they had to be as well" (Labor)

Most parties had no explicit strategy about who they wanted to communicate with. Some had no thoughts at all about this; some just said they wanted to engage potential 
voters, without saying anything about who their potential voters are. The Christian People's party is explicit about wanting to reach younger age groups, as their existing voters are mainly older people. The Liberal party has defined their typical voter as young and urban, and is trying to reach out to this group, but has no strategy about how they can accomplish this.

When - Everyone replied that they did not want to use SNS only during the election campaign. They point out that the use of SNS is not mainly a campaign tool, but part of a bigger strategy to engage in a dialogue with citizens: "IT goes without saying that the work we put in now will continue...There's a virtual world out there that is just as important to be present in as the real world...You just have to pay attention to what is happening and use the Internet for all it is worth" (Conservatives)

The Socialist Left party claims that the election campaign is less important than to maintain a constant dialogue and receive input from voters about their policy: "If you only use this during the election campaign...that is not the time policy is formed, so if you are serious about dialogue it does not make sense to stop after the election"

The Liberal party voiced some concern about time and resource constraints, and said that this could potentially be an obstruction to continued use: "These things tend to stop after the election. We don't want it to, but it takes an effort, both from politicians and us employees, and also some financial resources."

How - Parties were asked about how they wanted to communicate. If they wanted one- or two-way communication, to engage citizens in campaigning, how they wanted to structure communication, and what type of language they used in SNS.

There is broad agreement that content and language must be adapted to the specific medium. Interview subjects were eager to discuss blogs, and the importance of a less formal language and a more personal approach to writing came up several times during many of the interviews: "Contrary to what politicians are used to, you need to be more open, honest, listening, trying to write so that the audience are moved by the content, be humble" (Labor)

Contributions from citizens are also wanted, both in terms of policy debates and user-generated content. The Liberals, the Socialist Left and Labor announced competitions via YouTube, Twitter and Facebook, where they asked voters to create their own videos or web applications that the party could use.

Learning experience - 2007 was the first time that political parties experimented with SNS, and all of them provide tales of a steep learning curve. Labor and the Liberals point out that 2007 was an experiment, where the primary objective was to test new channels of communication: "We tried some things, and got some negative responses. Our objective has been to be first movers, because then you get a lot of coverage in the media. So quality was sometimes lacking” (Labor). The Center party was not very happy with their own efforts two years ago: "I am tempted to say that we do everything differently today"

\subsection{Genre Repertoire}

In the interviews, dialogue, contributions from citizens and involvement are mentioned as the overarching objective of party presence in SNSs. Table 1 presents these as genres, identified through the $5 \mathrm{~W} 1 \mathrm{H}$ method. These should be considered genre objectives, as there are many ways of creating dialogue, providing contributions or getting involved. 
Table 1. Genres identified in interviews

\begin{tabular}{|l|l|l|l|}
\hline Why & \multicolumn{1}{|c|}{ Dialogue } & \multicolumn{1}{|c|}{ Contribution } & \multicolumn{1}{|c|}{ Involvement } \\
\hline When & $\begin{array}{l}\text { Involve citizens in public } \\
\text { debate }\end{array}$ & $\begin{array}{l}\text { Knowledge about citizen } \\
\text { concerns }\end{array}$ & $\begin{array}{l}\text { Raise funds. Get } \\
\text { people to volunteer }\end{array}$ \\
\hline What & Continuous & Election time & Election time \\
\hline Who & $\begin{array}{l}\text { Conversation between citizens } \\
\text { and politicians/citizens and } \\
\text { citizens }\end{array}$ & Q\&A. Voter stories & $\begin{array}{l}\text { Competitions, } \\
\text { membership forms, } \\
\text { information }\end{array}$ \\
\hline Where & $\begin{array}{l}\text { Politicians, party members, } \\
\text { citizens }\end{array}$ & $\begin{array}{l}\text { Politicians, party } \\
\text { members, voters }\end{array}$ & Voters, sympathizers \\
\hline How & $\begin{array}{l}\text { SNS, web site } \\
\text { Encourage dialogue. } \\
\text { Open and personal language. } \\
\text { Citizen-generated content. }\end{array}$ & $\begin{array}{l}\text { Encourage contributions } \\
\text { and questions from } \\
\text { voters }\end{array}$ & $\begin{array}{l}\text { Competitions, theme } \\
\text { sites, cross- } \\
\text { publication }\end{array}$ \\
\hline
\end{tabular}

To identify the genres that make dialogue, contributions and involvement possible, I conducted a content analysis of the SNSs where the parties were present. Table 2 summarizes the identified genres, following the method created by Päivärinta, Halttunen and Tyrväinen [32]. The producers and users of information are identified to indicate the direction of communication. By mapping the medium the genre is presented through, we can learn something about which medium is suited for which genre. The final column shows which genre objective the genre is related to. When examining the individual Social network sites, we see how the functionality of the medium has great influence on communication. For example, Facebook wall posts and Twitter messages are very similar, but still produce very different outcomes because of the way they are presented.

Table 2. Genres identified through content analysis

\begin{tabular}{|l|l|l|l|l|}
\hline Genre & Producer & User & Medium & Related to \\
\hline Policy comment & Citizen & Citizen, party & $\begin{array}{l}\text { Facebook, blog, Origo, } \\
\text { Twitter, video }\end{array}$ & $\begin{array}{l}\text { Dialogue, } \\
\text { contribution }\end{array}$ \\
\hline Call for action & Citizen, party & Citizen & Facebook, Twitter, video & $\begin{array}{l}\text { Contribution, } \\
\text { involvement }\end{array}$ \\
\hline Q\&A & Citizen & Party & Facebook, Twitter, blog & Dialogue \\
\hline Appeal to party & Citizen & Party & Facebook, Twitter, blog & $\begin{array}{l}\text { Dialogue, } \\
\text { contribution }\end{array}$ \\
\hline Greeting & Citizen & Party & Facebook, blog & Dialogue \\
\hline Personal accounts & Citizen & Party & blog & Contribution \\
\hline Video response & Citizen, party & Citizen, party & YouTube & Contribution \\
\hline
\end{tabular}

The list presented in table 2 should not be considered complete. These are the genres that were present during the time of observation. Due to the changing nature of SNS, it is more than likely that new genres have been added. The list should be considered as a starting point for a more comprehensive mapping of genres, not as a finalized list. 
Policy comments are comments from citizens on party policy. These come in many forms. As Wall or discussion posts on Facebook or Origo, in Twitter messages, blog comments or as video responses. Video responses are rare, but not unheard of. Policy comments can be seen both as contributions to policy development and as part of a dialogue.

Calls for action mainly originate with the party, but are often distributed through citizens supporting the party making the call. This genre incorporates calls for volunteers, competitions and calls for action in specific cases. Several parties have created Facebook groups for parts of their policy. Calls are presented in video, with links to the video posted to Facebook and Twitter.

The Q\&A genre is perhaps the genre that citizens are least satisfied with. Many questions on Facebook walls remain unanswered, or are answered unsatisfactorily. Some citizens ask why politicians bother having a presence in SNS when they do not engage in conversations with citizens.

Appeals to the party are similar to policy comments. The difference is that where policy comments reflect directly on the party's political program, appeals are more specific, asking what the party intends to do with this or that matter. There is some frustration among citizens when these are not answered.

Greeting is an interesting genre. At his birthday, Prime Minister Jens Stoltenberg received hundreds of greetings wishing him a happy birthday. In other cases, we see greetings thanking the party for something they have done, or cheering them on to fight for a specific case. This genre, while not directly political, could be seen as narrowing the gap between politician and citizen, creating a sense of personal attachment between the two.

Personal accounts are mainly found in blogs, as response to politicians asking for the stories of individual citizens. The most interesting example is where the minister of health asks for people's stories as input to a major health reform. This initiative generated around a thousand replies from citizens wanting to share their experiences with the Norwegian health system.

Video responses from citizens are rare, but some examples exist. These can be either interviews where citizens respond to something politicians have said, or responses to the competitions where parties ask citizens to contribute. There are also responses between parties, where video is used in a similar manner to newspaper debates, and responses between politicians belonging to the same party.

Even though we see an emerging genre repertoire in political communication through SNS, the content analysis shows that there are some challenges that need to be addressed. The main problem, especially with the policy comment, Q\&A and appeal to party genres, is that for some, communication is still mostly one-way. Some parties and politicians are not responding to questions, and comments and appeals are even less likely to receive answers, while others are better at responding. On the other hand, calls for action and policy comments where parties have asked for comments, receives a lot of attention and feedback. This is in line with other research, claiming that political use of SNS is not yet following web 2.0 principles fully, but rather functions as a "web 1.5" [34]. 


\section{Conclusion}

Political parties in Norway report that they are serious about using SNS to create dialogue, contributions and involvement from citizens. They want to increase political awareness in the population, get sympathizers to participate in offline activities, and to have citizens influence policy development. They report that this is not just an election time activity, but something they want to continue doing after the election in order to create a better dialogue between party and citizen.

The content analysis shows that while there has in fact been developing a genre repertoire for political communication in SNS, there is little agreement on how some of these genres should be enacted. Genres involving citizen-initiated dialogue are the most problematic, while politician-initiated genres have more success. This could be because politicians still are uncertain about how to communicate in SNS, and what communication through SNS should mean for the political process. It could also be a question of politicians and citizens not understanding the genre, and not understanding the appropriate level of democracy for each individual genre. Further research should address this, and develop a genre repertoire that helps politicians and citizens to reach a mutual understanding of what they are communicating about, as well as what the outcome of communication should be. Genre theory and democracy models have demonstrated the communicative gap between politicians and citizens, and could prove useful in closing this gap.

\section{References}

1. Hestvik, H.: Valgkamp2001.no. Partier, velgere og nye medier. Ny kommunikasjon? In: Aardal, B., Krogstad, A., Narud, H.M. (eds.) I valgkampens hete: strategisk kommunikasjon og politisk usikkerhet. Universitetsforlaget, Oslo (2001)

2. Edelman, The Social pulpit. Barack Obama's social media Toolkit (2009)

3. Østerud, Ø., Engelstad, F., Selle, P.: Makten og demokratiet: en sluttbok fra Makt- og demokratiutredningen. Gyldendal akademisk, Oslos (2003)

4. Sæbø, Ø., Rose, J., Skiftenes Flak, L.: The shape of eParticipation: Characterizing an emerging research area. Government Information Quarterly 25(3), 400-428 (2008)

5. Tambouris, E., Liotas, N., Tarabanis, K.: A Framework for Assessing eParticipation Projects and Tools. In: Hawaii International Conference on System Sciences, Hawaii (2007)

6. Brandtzæg, P.B., Lüders, M.: eCitizen 2.0: The Ordinary Citizen as a Supplier of Public Sector Information. Ministry for Government and Administration Reform, Oslo (2008)

7. Dahlberg, L.: The Internet and Democratic Discourse: Exploring The Prospects of Online Deliberative Forums Extending the Public Sphere. Information, Communication \& Society 4(4), 615-633 (2001)

8. Sæbø, Ø., Päivârinta, T.: Autopoietic cybergenres for e-Democracy? Genre analysis of a web-based discussion board. In: Hawaii International Conference on System Sciences (2005) 
9. Komito, L.: e-Participation and Governance: Widening the net. The Electronic Journal of e-Government 3(1), 39-48 (2005)

10. Sanford, C., Rose, J.: Characterizing eParticipation. International Journal of Information Management 27(6), 406-421 (2007)

11. Ekelin, A.: To be or not to be active: Exploring practices of e-participation. Springer, Berlin (2006)

12. Rose, J., Sæbø, Ø.: Democracy Squared: Designing On-Line Political Communities to Accommodate Conflicting Interests Scandinavian. Journal of Information Systems 17(2) (2005)

13. Päivärinta, T., Sæbø, Ø.: Models of E-democracy. Communications of the Association for Information Systems 17(4) (2006)

14. Bughin, J., Manyika, J., Miller, A.: McKinsey global survey results: Building the web 2.0 enterprise. In: McKinsey Quarterly survey on web 2.0 (July 2008)

15. Tapscott, D., Williams, A.: Wikinomics: How mass collaboration changes everything., 2nd edn. Portfolio/Penguin Group, New York (2008)

16. O'Reilly, T.: What is web 2.0? Design patterns and business models for the next generation of software (2005),

http: / / oreilly.com/web2/archive/what-is-web-20.html

(cited September 2, 2010)

17. User centric media: Future and challenges in european Research, European Commission: Information society and media (2007)

18. Enders, A., et al.: The long tail of social networking. Revenue models of social networking sites. European Management Journal 26(3) (2008)

19. OECD, Participative web and User-created Content: Web 2.0, wikis and social networking, OECD (2007)

20. Boyd, d.m., Ellison, N.B.: Social Network Sites: Definition, History, and Scholarship. Journal of Computer-Mediated Communication 13(1), 210-230 (2008)

21. Anderson, P.: What is Web 2.0? Ideas, technologies and implications for education. In: JISC Technology and Standards Watch (2007)

22. Rose, J., et al.: The role of social networking software in eParticipation, in DEMO-net: D14.3. In: Svendsen, S.B. (ed.) DEMO-net: The Democracy Network (2007)

23. Aardal, B., Krogstad, A., Narud, H.M.: I valgkampens hete: strategisk kommunikasjon og politisk usikkerhet, p. 431. Universitetsforl, Oslo (2004)

24. Aardal, B., Holth, I.J.: Norske velgere: en studie av stortingsvalget 2005, p. 381. Damm, Oslo (2007)

25. Fredriksen, A., Alnes, E.: Valgseier med hjelp av Internett, NRK (2009)

26. Karlsen, R.: Den første internettvalgkampen? Velgernes informasjonskilder. In: Aardal, B., Holth, I.J. (eds.) Norske velgere: en studie av stortingsvalget 2005. Damm, Oslo (2007)

27. Kalnes, Ø.: Norwegian Parties and Web 2.0. Journal of Information Technology and Politics 6(3), 251-266 (2009)

28. Andresen, S.: Valgkamp på nett: partilederes bruk av blogg som politisk kommunikasjonsverktøy i valget 2007. S. Andresen, Oslo (2008)

29. Yates, J., Orlikowski, W.J.: Genres of Organizational Communication: A Structurational Approach to Studying Communication and Media. The Academy of Management Review 17(2), 299-326 (1992)

30. Orlikowski, W.J., Yates, J.: Genre Repertoire: The Structuring of Communicative Practices in Organizations. Administrative Science Quarterly 39(4), 541-574 (1994) 
31. Shepherd, M., Watters, C.: The evolution of cybergenres. In: Proceedings of the ThirtyFirst Hawaii International Conference on System Sciences (1998)

32. Päivärinta, T., Halttunen, V., Tyrväinen, P.: A Genre-Based Method for Information Systems Planning. In: Rossi, M., Siau, K. (eds.) Information Modeling in the New Millenium, pp. 70-93. Idea Group Publishing, Hershey (2001)

33. Yoshioka, T., et al.: Genre taxonomy: A knowledge repository of communicative actions. ACM Trans. Inf. Syst. 19(4), 431-456 (2001)

34. Jackson, N.A., Lilleker, D.G.: Building an Architecture of Participation? Political Parties and Web 2.0 in Britain. Journal of Information Technology and Politics 6(3), 232-250 (2009) 